\title{
Milk Production Responses and Digestibility of Dairy Buffaloes (Bubalus bubalis) Partially Supplemented with Forage Rape (Brassica napus) Silage Replacing Corn Silage
}

\author{
Di Zhou ${ }^{1,+}$, Mohamed Abdelrahman ${ }^{1,2,+}{ }^{\mathbb{D}}$, Xinxin Zhang ${ }^{1}$, Shuai Yang ${ }^{1}$, Jing Yuan ${ }^{1}$, Zhigao An ${ }^{1} \mathbb{D}$, \\ Kaifeng Niu ${ }^{1}$, Yanxia Gao ${ }^{3}{ }^{(0}$, Jianguo $\mathrm{Li}^{3}{ }^{3}$, Bo Wang ${ }^{4}$, Guangsheng Zhou ${ }^{4}$, Liguo Yang ${ }^{1,5, *}$ and Guohua Hua ${ }^{1,5, *}$
}

1 Key Laboratory of Animal Genetics, Breeding and Reproduction, Ministry of Education, College of Animal Science and Technology, Huazhong Agricultural University, Wuhan 430070, China; hzau_judy_213@163.com (D.Z.); mohamed.asad@agr.au.edu.eg (M.A.); zxx1144795936@163.com (X.Z.); ys1105216413@163.com (S.Y.); 17806243701@163.com (J.Y.); anzhigao95@foxmail.com (Z.A.); nkf_19930806@163.com (K.N.)

2 Animal Production Department, Faculty of Agriculture, Assuit University, Asyut 71515, Egypt

3 College of Animal Science and Technology, Hebei Agricultural University, Baoding 071000, China; yxgaohebau@126.com (Y.G.); jgli@hebau.edu.cn (J.L.)

4 Key Laboratory of Crop Ecophysiology and Farming System in the Middle Reaches of the Yangtze River, College of Plant Science and Technology, Huazhong Agricultural University, Wuhan 430070, China; wangbo@mail.hzau.edu.cn (B.W.); zhougs@mail.hzau.edu.cn (G.Z.)

Citation: Zhou, D.; Abdelrahman, M.; Zhang, X.; Yang, S.; Yuan, J.; An Z.; Niu, K.; Gao, Y.; Li, J.; Wang, B.; et al. Milk Production Responses and Digestibility of Dairy Buffaloes (Bubalus bubalis) Partially Supplemented with Forage Rape (Brassica napus) Silage Replacing Corn Silage. Animals 2021, 11, 2931

https://doi.org/10.3390/ani11102931

Academic Editors: Alfredo Pauciullo and Gianfranco Cosenza

Received: 20 August 2021

Accepted: 7 October 2021

Published: 10 October 2021

Publisher's Note: MDPI stays neutral with regard to jurisdictional claims in published maps and institutional affiliations.

Copyright: (c) 2021 by the authors. Licensee MDPI, Basel, Switzerland. This article is an open access article distributed under the terms and conditions of the Creative Commons Attribution (CC BY) license (https:// creativecommons.org/licenses/by/ $4.0 /)$.
5 Hubei Province Buffalo Engineering Center, Wuhan 430070, China

* Correspondence: ylg@mail.hzau.edu.cn (L.Y.); huaguohua@mail.hzau.edu.cn (G.H.); Tel.: +86-138-7105-6592 (L.Y.); +86-136-3860-4846 (G.H.)

+ These authors contributed equally to this work.

Simple Summary: To develop alternative silage resources, we employed buffaloes as an animal model to evaluate the possibility and effects of forage rape silage in the dairy buffalo diet. We comprehensively assessed the nutrition value of forage rape silage by the apparent total-tract digestibility, rumen fermentation characteristics, blood metabolism and milk composition of lactating buffaloes. Our current results showed that the inclusion of forage rape silage in diets improved the milk quality, such as milk protein, milk fat, and total solid percentage. Furthermore, partial supplementation of forage rape silage also promotes buffaloes' dry matter intake. These may be related to the favorable physiological and metabolic changes induced by the forage rape silage. Thus, our current data show the applicability of forage rape silage as a good feed resource for ruminants.

Abstract: Worldwide, silage is considered the main component in dairy animal diets; however, this portion is mainly dominated by corn silage, which raises availability challenges in some agricultural production systems. The present study evaluated a partial replacement of corn silage with forage rape silage (FRS) and its effect on feed intake, nutrient digestibility, rumen fermentation, milk production, and blood metabolites in buffalo. Thirty-six lactating buffaloes were randomly assigned to four different groups, according to supplementation of FRS (only corn silage, $\mathrm{FRS}_{0}$ ) or with $15 \%\left(\mathrm{FRS}_{15}\right)$, $25 \%\left(\mathrm{FRS}_{25}\right)$, and $35 \%\left(\mathrm{FRS}_{35}\right)$ of forage rape silage instead of corn silage. The results showed that, compared to corn silage, forage rape silage has a lower carbohydrate but a higher protein concentration. The buffalo intake of dry matter and organic matter were improved linearly with the FRS increasing in the diet. The apparent total-tract digestibility (ATTD) of dry matter, organic matter, nitrogen, neutral detergent fiber, and acid detergent fiber also increased by the FRS supplementation compared with $\mathrm{FRS}_{0}$. Conversely, FRS supplementation decreased the propionic, butyric, and valeric acid contents and increased the acetic:propionic ratio and microbial protein content. Furthermore, FRS inclusion led to a significantly higher milk urea and non-fat milk solid content, higher blood glucose, total globulins, blood urea nitrogen, and lower blood high-density lipoprotein. These results suggested that FRS has high a nutritional value and digestibility, is a good feed resource, and showed favorable effects when supplemented with dairy buffalo ration. 
Keywords: forage rape silage; buffalo; digestibility; milk composition; rumen fermentation

\section{Introduction}

Recently, dairy ruminant production systems, especially buffalo, have been concerned with using high nutritive-yielding crops as a complementary forage source [1-5]. The brassica family, especially forage rape (Brassica napus), attracted valuable ruminant forage. Forage rape is considered a kind of high-quality green-forage source that is strongly preferred for its cultivating and feeding characteristics. In addition to the growing ability under the water-limited condition and high growth rate in the cold season [6], forage rape is considered as a high-yielding dry matter crop [7] and is easily intercropped with legumes [8]. Most importantly, forage rape is distinguished with its high nutritional value, especially the high metabolizable energy level (2.8 3.0 Mcal/kg dry matter (DM)), besides the readily fermentable carbohydrates, high crude protein (CP) (160 to $200 \mathrm{~g} / \mathrm{kg} \mathrm{DM})$, and low fiber content $[9,10]$. Interestingly, feeding the brassica family and forage rape could also reduce methane emissions per unit of DM intake in ruminants, promoting its inclusion in ruminant diets [8-11]

Despite the high nutritional characteristics of brassica-family forages $[9,10]$, the precise effects on dairy animal performance are much debated. In the recent literature, contradicting findings on milk production efficiency have emerged; for example, researchers reported the negative impact of feeding summer turnips (Brassica rapa) on milk production [11]. However, others mentioned that supplementing dairy cows with forage rape could improve milk production [12].

Questions have been raised about the sustainability of the on-farm fresh forage rape usage due to some limitations. One concern is that the low fiber content may induce a rapid rumen $\mathrm{pH}$ drop, affecting nutrient metabolism and other dietary components' digestibility. Furthermore, the presence of high levels of antinutritional factors, such as the relatively high level of nitrates, increases the incidence of nitrites toxicity and even death of the animal [13]. In addition, secondary compounds (e.g., S-methyl-cysteine sulphoxide (SMCO) and glucosinolates) that mainly exist in brassicas in higher concentrations compared to other forage types also raised concerns. Likewise, the higher content of nitrogen $(\mathrm{N})$ in forage rape may affect animal health through excessive rumen ammonia absorption [14].

It was previously known that the ensiling process could improve the forage quality, especially by inhibiting antinutritional factors. Unfortunately, studies that discussed ensilaged forage rape are limited; moreover, the investigations that assess dairy buffalo utilization for forage rape silage (FRS) are also scarce. Our previous study successfully introduced a forage rape silage method [14]. Therefore, this study aimed to evaluate the potentials of FRS inclusion on dairy buffalo performance, the ruminal fermentation pattern, and milk production response.

\section{Materials and Methods}

\subsection{Animals, Diets, and Experiment Design}

Thirty-six Mediterranea $\times$ Nili-Ravi hybrid lactating buffaloes were utilized for feeding experiments at the Hubei Jinniu Buffalo Farm (Hubei, China). Animals were randomly assigned to 4 groups according to initial milk yield, days in milking (DIM), lactation number, and bodyweight (BW) (mean $\pm \mathrm{SD}$ ), which were $5.1 \pm 1.2 \mathrm{~kg} /$ day, $101 \pm 76$ days, $2.3 \pm 1.1,605 \pm 86 \mathrm{~kg}$, respectively. The diet was offered twice (at 600 and $1500 \mathrm{~h}$ ) daily, while all animals had free access to water.

Forage rape (Brassica napus L.) cultivar ('Huayouza 62') were sown in late September 2018 and harvested in early April 2019. The plants were cut at the final flowering stage, air-dried for $72 \mathrm{~h}$ until the dry matter was over $30 \%$. After harvesting, plants were chopped to a 3 5-centimeter length using a lawn mower, then mixed with corn meal (processed from corn kernels) (Northeast Treasury Corn Jilin, Jilin, China), brown sugar (from Fengtang 
Zhikang Brown-Sugar Factory, Chaozhou, China), and a bacterial inoculants mixture for the silage process. The bacterial mixture contained solid and liquid bacterial agents; the solid agents were Lactobacillus Plantarum, Lactobacillus acidophilus, Lactobacillus brucei, Lactobacillus casei, cellulase, effective live bacteria $\geq 4 \times 10^{9} \mathrm{CFU} / \mathrm{g}$. However, the liquid agents were Lactobacillus plantarum, Lactobacillus acidophilus, Pediococcus pentosaceus, organic acids, small molecule peptides, effective live bacteria $\geq 2 \times 10^{9} \mathrm{CFU} / \mathrm{g}$ (Shandong Zhuohua Biological Company, Jinan, China). At Hubei Jinniu Buffalo Farm, the chopped forage rape was spread and compacted in a silage bunker layer by layer (each layer about a 20 30-centimeter height), then evenly sprayed with the mixture of the bacterial agents and corn meal in each layer, finally sealing. Each ton of chopped forage rape was treated by a bacterial inoculants' mixture containing $2 \mathrm{~L}$ of water and $0.2 \mathrm{~kg}$ of brown sugar, with a water temperature adjusted to between 30 and $37^{\circ} \mathrm{C}$; this was then well mixed with $25 \mathrm{~g}$ of a solid bacterial agent, $250 \mathrm{~mL}$ of a liquid bacterial agent and $10 \mathrm{~kg}$ of corn flour.

The experiment provided four total mixed ration(TMR) diets, and its ratio of roughage to concentrate was 65:35 (calculated on dry matter basis), and the forage rape silage to corn silage (FRS:CS ratio) (on a fresh matter (FM) basis) in the diet was 0:100 (FRS $)_{0}$ and 15:85 $\left(\mathrm{FRS}_{15}\right), 25: 75\left(\mathrm{FRS}_{25}\right)$, and 35:65 $\left(\mathrm{FRS}_{35}\right)$, respectively. All diets contain (on a dry matter basis) $15 \%$ straw, $15 \%$ corn meal, $7 \%$ soybean meal, and $15 \%$ yeast culture. The chemical composition of each ingredient is listed in Table 1 , and Table 2 provides the nutritive value characteristics of the four experimental diets. The study lasted for 73 days, the first 10 days as a feeding-adaptation period and a 63-day experimental period.

Table 1. Chemical composition of feed ingredients.

\begin{tabular}{|c|c|c|c|c|c|c|}
\hline Parameter (\%DM) & Forage Rape Silage & Corn Silage & Straw & Corn Meal & Soybean Meal & DDGS \\
\hline Dry matter (DM) & 30.77 & 21.67 & 85.32 & 89.64 & 90.61 & 89.94 \\
\hline Organic Matter (OM) & 88.58 & 92.7 & 87.16 & 98.08 & 93.33 & 90.48 \\
\hline $\mathrm{CP}$ & 11.74 & 8.74 & 4.11 & 13.05 & 42.81 & 20.36 \\
\hline Ether extract & 2.94 & 2.58 & 1.00 & 3.52 & 2.27 & 4.64 \\
\hline $\begin{array}{l}\text { Water-soluble } \\
\text { carbohydrates }\end{array}$ & 2.77 & 7 & 6.28 & 12.68 & 12.91 & 7.93 \\
\hline $\begin{array}{l}\text { Neutral Detergent Fiber } \\
\text { (NDF) }\end{array}$ & 51.13 & 54.32 & 51.9 & 5.72 & 12.8 & 34.26 \\
\hline $\begin{array}{l}\text { Acid Detergent fiber } \\
\text { (ADF) }\end{array}$ & 34.4 & 28.67 & 31.51 & 0.88 & 7.47 & 21.84 \\
\hline $\begin{array}{l}\text { Acid Detergent Lignin } \\
\text { (ADL) }\end{array}$ & 5.63 & 2.87 & 1.59 & $\mathrm{ND}^{1}$ & ND & 5.6 \\
\hline
\end{tabular}

${ }^{1} \mathrm{ND}=$ not determined

Table 2. Ingredients and chemical composition of the experimental diets.

\begin{tabular}{ccccc}
\hline & & \multicolumn{3}{c}{ Diets $^{\mathbf{1}}$} \\
\cline { 2 - 5 } Item & FRS $_{\mathbf{0}}$ & FRS $_{\mathbf{1 5}}$ & FRS $_{\mathbf{2 5}}$ & FRS $_{\mathbf{3 5}}$ \\
\hline Ingredient (\%DM) & & & & \\
\hline Forage rape silage & 0 & 9.87 & 16.21 & 22.36 \\
Corn silage & 46.20 & 38.03 & 32.84 & 27.79 \\
Straw & 15.52 & 15.03 & 14.70 & 14.38 \\
Corn meal & 15.62 & 15.13 & 6.66 & 6.51 \\
Soybean meal & 7.03 & 6.81 & 14.80 & 14.48 \\
DDGS & 15.62 & 15.13 & - & - \\
Brick lick & - & - & & \\
\hline
\end{tabular}


Table 2. Cont.

\begin{tabular}{|c|c|c|c|c|}
\hline \multirow{2}{*}{ Item } & \multicolumn{4}{|c|}{ Diets $^{1}$} \\
\hline & FRS $_{0}$ & FRS $_{15}$ & FRS $_{25}$ & FRS $_{35}$ \\
\hline \multicolumn{5}{|c|}{ Chemical composition } \\
\hline OM, \% of DM & 92.37 & 90.97 & 90.69 & 90.19 \\
\hline $\mathrm{CP}, \%$ of DM & 12.25 & 13.17 & 13.52 & 14.16 \\
\hline Ether extract, \% of DM & 2.17 & 2.31 & 2.98 & 3.71 \\
\hline Water Soluble Carbohydrate (WSC), \% of DM & 7.06 & 5.61 & 3.71 & 5.61 \\
\hline NDF, $\%$ of DM & 33.52 & 35.37 & 37.09 & 37.68 \\
\hline $\mathrm{ADF}, \%$ of $\mathrm{DM}$ & 20.05 & 23.06 & 24.22 & 24.33 \\
\hline
\end{tabular}

1 Experimental diets were composed of forage and concentrates (83:17), with targeted levels of forage rape silage (FRS):corn silage $(C S)=0: 100,15: 85,25: 75$, and 35:65 on an FM basis. ${ }^{2}$ A lick brick weighs $5 \mathrm{~kg}$ and consists of $98 \%$ salt, 25 mg of calcium, $250 \mathrm{mg}$ of phosphorus, $1000 \mathrm{mg}$ of magnesium, $20 \mathrm{mg}$ of selenium, $150 \mathrm{mg}$ of copper, $50 \mathrm{mg}$ of cobalt, $500 \mathrm{mg}$ of iron, and $200 \mathrm{mg}$ of manganese in each group of four lick bricks.

\subsection{Sampling and Chemical Analyses}

\subsubsection{Feed}

Feed samples of the four experimental were collected at 9 a.m. on the 3rd, 24th, and 45th day of the experimental period. All feeding samples were dried at $65{ }^{\circ} \mathrm{C}$ for $48 \mathrm{~h}$ to determine the initial moisture content. Then, samples were grinded using a multifunctional pulverizer (Old Bank Boou Hardware Factory, Zhejiang, China) and passed through a 40-mesh sieve (manufactured by Tianxing Wusi Yarn Sieve Factory in Shangyu City, Zhejiang, China) to be stored at $-20^{\circ} \mathrm{C}$ for further analysis. The dry matter (DM), crude ash (CA), crude protein (CP), ether extract (EE), neutral detergent fiber (NDF), acid detergent fiber (ADF), acid detergent lignin (ADL), and acid insoluble ash (AIA) of feed were determined according to the Association of Official Analytical Chemists (1995) [15], and by described methods $[16,17]$ and concentrations of NDF and ADF, both inclusive of residual ash, and ADL, were determined with the ANKOM Filter Bag Method. Both Heat-stable $\alpha$-amylase and sodium sulphite were added during NDF extraction [18,19]. Water-soluble carbohydrates (WSC) concentration was determined using the anthrone sulphate method [20].

\subsubsection{Feces and Rumen Fluid Sampling and Analysis}

Randomly selected three buffaloes with similar body conditions were reared individually for the apparent total-tract digestibility (ATTD) analysis. Each experimental diet included a 7-day adaptation period and a three-day experimental period (fed once a day, weighed diet, and the refusals). Fecal samples were collected at 9:00 and 17:00 every day, $600 \mathrm{~g}$ per buffalo (based on FM), and all fecal in one day to be mixed. Mixed fecal samples for every day were divided into two parts. One was added with $20 \mathrm{~mL}$ of $10 \% \mathrm{H}_{2} \mathrm{SO}_{4}$ per $100 \mathrm{~g}$ of fresh fecal for fixing nitrogen [18], and then the another was stored directly at $-20{ }^{\circ} \mathrm{C}$ for further analysis. Thawed fecal samples were dried and grinded to pass through a 40-mesh sieve. Concentrations of NDF and ADF in fecal were analyzed as described above. In addition, fresh fecal samples were analyzed for DM and CA, using the methods mentioned above, and nitrogen $(\mathrm{N})$ using the Kjeldahl method.

Rumen fluid was collected by a ruminal content sampling tube (MDW16, Sichuan, China) from three buffaloes of each group $2 \mathrm{~h}$ after the morning diet on the 2nd and 62 nd days. The collected rumen fluid was immediately filtered with a sterile 4-layer gauze, and the filtrate was divided into 10-milliliter Eppendorf tubes to be treated [21]. First, the rumen fluid $\mathrm{pH}$ was measured immediately using a $\mathrm{pH}$ meter (FE-20-FiveEasy PlusTM, Mettler Toledo Instruments Co., Ltd., Shanghai, China). Then, $10 \mathrm{~mL}$ of rumen fluid and $0.1 \mathrm{~mL}$ of $6 \mathrm{~mol} / \mathrm{L}$ hydrochloric acid were mixed to fix ammonia-N. After that, $5 \mathrm{~mL}$ of rumen fluid was centrifuged $(10,000 \times g, 10 \mathrm{~min})$ using a refrigerated centrifuge (Thermo election corporation). Next, $1.5 \mathrm{~mL}$ of its supernatant was taken to be mixed with $0.15 \mathrm{~mL}$ of metaphosphoric acid ( $25 \%$ ), shake homogenized, left to stand for $30 \mathrm{~min}$, and centrifuged 
again $(10,000 \times g, 15 \mathrm{~min})$; the supernatant was taken for the determination of volatile fatty acid (VFA) [22]. Fresh and treated samples were stored at $-20{ }^{\circ} \mathrm{C}$ for further analysis. The ammonia-N concentration was determined using Phenol-sodium hypochlorite colorimetry [23], the concentration of microbial protein (MCP) was determined using the Coomassie brilliant blue method, and gas chromatography was used for the analysis of VFA concentrations [24].

\subsubsection{Milk}

Milk samples were taken at 500 and $1500 \mathrm{~h}$ every day, and the milk yield was recorded. In addition, milk samples were collected from each buffalo once per day, alternating morning and afternoon milking from the 15th and 16th day of each period. Milk samples were $1: 1$ mixed and conserved with preservative $(0.2 \mathrm{~g}$ of bronopol solution $/ 40 \mathrm{~mL}$ of milk), kept refrigerated at $4{ }^{\circ} \mathrm{C}$, and afterwards analyzed for fat, total protein, lactose, and urea at an official milk control laboratory (Hubei Provincial Animal husbandry Bureau, Wuhan, China), using Fourier transform infrared spectroscopy (MilkoScan 7RM, FOSS Analytical, Hillerød, Denmark) [25].

\subsubsection{Blood}

On the 5th and 58th day of the experiment, six buffaloes of each group were randomly selected for $20 \mathrm{~mL}$ of blood to be collected from the neck vein using heparinized vacuum tubes $2 \mathrm{~h}$ after the morning feeding. Each sample was mixed gently and centrifuged at $3000 \mathrm{r} / \mathrm{min}$ for $15 \mathrm{~min}$ at room temperature (low-speed centrifuge, SCIL0GEX, Beijing, China). Plasma was recovered, transferred to plastic vials, and frozen at $-20{ }^{\circ} \mathrm{C}$ for analysis of biochemical blood parameters. The total protein (TP), blood urea nitrogen (BUN), glucose (Glu), total cholesterol (TC), triglycerides (TG), high-density lipoprotein (HDL), and low-density lipoprotein (LDL) were detected using a biochemical analyzer (automatic biochemical analyzer, BS-420, Shenzhen Mindray, Guangdong, China). In addition, alanine aminotransferase (ALT), aspartate aminotransferase (AST), glutamyltransferase (GGT), and lactate dehydrogenase (LD) were tested by kits (Nanjing Jiancheng, Nanjing Jiancheng Institute of Biological Engineering Limited, Nanjing, China) [26].

\subsection{Calculations and Statistical Analyses \\ 2.3.1. Calculations}

The dry matter intake (DMI) calculation formula was DMI = feed intake (kg/day) $\times \mathrm{DM}$ content of the feed (\%). Assuming a fecal recovery of acid-insoluble ash (AIA) is $100 \%[27,28]$, the fecal OM content was calculated by measuring the crude ash content in the feces. Apparent Total-tract digestibility (ATTD) for DM, OM, NDF, and ADF was calculated in a group as ATTD $\%=100 \times(1-$ (nutrient in Fecal $\times$ AIA in diet) $/$ (nutrient in diet $\times$ AIA in Fecal)).

\subsubsection{Statistical Analyses}

All statistical analyses were analyzed using SAS 9.4 (SAS Institute, Cary, NC, USA, 2017). Data were normally distributed and homoscedastic. The following statistical mixed model (repeated measure) was used for all variables (except for ATTD, and rumen fluid index):

$$
Y_{i j k}=\mu+\tau_{i}+\delta_{i j}+t_{k}+(\tau \times t)_{i k}+\varepsilon_{i j k}
$$

where $Y_{i j k}$ is the dependent variable, $\mu$ is the overall mean, $\tau_{i}$ is the fixed effect of dietary treatment $i, t_{k}$ is the random effect of time, $(\tau \times t)_{i k}$ is the interaction effect of group and time, $\delta_{\mathrm{ij}}$ is the random effect of covariance between repeated measures in an individual, and $\varepsilon_{\mathrm{ijk}}$ is the random error of the variance between the measures within the individual. ATTD and rumen fluid index were analyzed according to the following model (one-way ANOVA):

$$
Y_{i j}=\mu+\tau_{i}+\varepsilon_{i j}
$$


where $Y_{i j k}$ is the dependent variable, $\mu$ is the overall mean, $\tau_{i}$ is the fixed effect of dietary treatment $i$, and $\varepsilon_{i j}$ is the random residual error. Data were analyzed using an ANOVA way to identify treatment effects. Additionally, multiple contrast tests related to Tukey were conducted for treatment comparisons. Additionally, orthogonal polynomial contrasts were used to test for linear and quadratic effects of RS levels on response variables. All reported values are least significant means (LSM), and significance was declared at $p<0.05$.

\section{Result}

\subsection{Feed Intake and Apparent Total-Tract Digestibility}

Forage rape supplementation effects on a buffalo's feed intake and apparent total-tract digestibility (ATTD) are shown in Table 3. Increasing the proportion of FRS in the diet linearly raised the DMI from 9.33 to $10.47 \mathrm{~kg} /$ day $(p<0.0001)$, and the OM intake from 8.00 to $8.86 \mathrm{~kg} /$ day $(p<0.0001)$, respectively. Supplementation of $25 \%\left(\mathrm{FRS}_{25}\right)$ and $35 \%$ $\left(\mathrm{FRS}_{35}\right)$ FRS significantly improved the DMI by 16.9 and $12.2 \%$ compared with that in the FRS $_{0}$ group. Supplementation of 25 and $35 \%$ of FRS also significantly increased the OM intake by 14.6 and $10.8 \%$, respectively.

Table 3. Feed intake and apparent total-tract digestibility in lactating buffaloes fed the four experimental diets.

\begin{tabular}{|c|c|c|c|c|c|c|c|c|}
\hline \multirow{2}{*}{ Item } & \multicolumn{4}{|c|}{ Diets $^{1}$} & \multirow{2}{*}{ SEM } & \multicolumn{3}{|c|}{$p$-Value ${ }^{2}$} \\
\hline & $\mathrm{FRS}_{0}$ & FRS $_{15}$ & FRS $_{25}$ & FRS $_{35}$ & & Diet & $\mathbf{L}$ & Q \\
\hline \multicolumn{9}{|c|}{ Intake, $\mathrm{kg} /$ day } \\
\hline $\mathrm{DM}$ & $9.33^{b}$ & $9.65^{b}$ & $10.91^{\mathrm{a}}$ & $10.47^{\mathrm{a}}$ & 0.1793 & $<0.0001$ & $<0.0001$ & 0.0173 \\
\hline $\mathrm{OM}$ & $8.00^{b}$ & $8.07^{b}$ & $9.17^{\mathrm{a}}$ & $8.86^{\mathrm{a}}$ & 0.1508 & 0.0001 & $<0.0001$ & 0.1070 \\
\hline \multicolumn{9}{|c|}{ ATTD, $\%$} \\
\hline DM & $59.31^{c}$ & $65.83^{\mathrm{a}}$ & $62.54^{b}$ & $54.48^{\mathrm{d}}$ & 0.6811 & $<0.0001$ & 0.0004 & $<0.0001$ \\
\hline $\mathrm{OM}$ & $62.25^{b}$ & $68.61^{a}$ & $65.26^{\mathrm{ab}}$ & $57.30^{c}$ & 0.7404 & $<0.0001$ & 0.0006 & $<0.0001$ \\
\hline $\mathrm{N}$ & $61.53^{c}$ & $64.17^{a b}$ & $64.90^{\mathrm{a}}$ & $62.10^{b c}$ & 0.5723 & 0.0087 & 0.3646 & 0.0014 \\
\hline NDF & $42.21^{\mathrm{C}}$ & $53.53^{a b}$ & $55.79^{a}$ & $44.61^{b c}$ & 1.9912 & 0.0032 & 0.3199 & 0.0005 \\
\hline $\mathrm{ADF}$ & $35.02^{b}$ & $52.29^{a}$ & $54.72^{\mathrm{a}}$ & $36.33^{b}$ & 2.3448 & 0.0005 & 0.5608 & $<0.0001$ \\
\hline
\end{tabular}

${ }^{\mathrm{a}-\mathrm{d}}$ LSM within the same row with different superscripts differ $(p<0.05) .{ }^{1}$ Experimental diets were composed of forage and concentrates (83:17), with targeted levels of forage rape silage (FRS):corn silage (CS) $=0: 100,15: 85,25: 75$, and 35:65 on an FM basis. ${ }^{2} \mathrm{~L}=$ linear effect; $\mathrm{Q}=$ quadratic effect.

The $\mathrm{FRS}_{15}$ and $\mathrm{FRS}_{25}$ diets significantly promoted apparent total-tract DM, OM, N, $\mathrm{NDF}$, and ADF digestibility (Table 3 ). However, the $\mathrm{FRS}_{35}$ treatment showed a deteriorated apparent total-tract DM and OM digestibility $(p<0.05)$. Moreover, the apparent total-tract NDF and ADF digestibility of the $\mathrm{FRS}_{15}$ and $\mathrm{FRS}_{25}$ diets were significantly enhanced compared with $\mathrm{FRS}_{0}$ and $\mathrm{FRS}_{35}$. Meanwhile, $\mathrm{N}$ digestibility also significantly increased in the $\mathrm{FRS}_{15}$ and $\mathrm{FRS}_{25}$ treatments compared to the $\mathrm{FRS}_{0}$ and $\mathrm{FRS}_{35}$ diets.

\subsection{Rumen Fermentation Characteristics}

It was observed that $\mathrm{pH}$ and ammonia-N levels were not affected by FRS inclusion; however, the $\mathrm{FRS}_{25}$ and $\mathrm{FRS}_{35}$ diets showed a 16-17\% lower ammonia nitrogen concentration than detected in the $\mathrm{FRS}_{0}$ and $\mathrm{FRS}_{15}$ groups. Moreover, the microbial protein content $(5.85 \mathrm{mg} / \mathrm{mL})$ of the $\mathrm{FRS}_{25}$ diet is significantly $(p<0.0001)$ higher than $\mathrm{FRS}_{0}, \mathrm{FRS}_{15}$, and $\mathrm{FRS}_{35}\left(2.52,3.25\right.$, and $2.05 \mathrm{mg} / \mathrm{mL}$, respectively). Additionally, the $\mathrm{FRS}_{25}$ diet dramatically increased the microbial protein content $(5.85 \mathrm{mg} / \mathrm{mL})$; however, the highest FRS level $\left(\mathrm{FRS}_{35}\right)$ recorded the lowest microbial protein content $(2.05 \mathrm{mg} / \mathrm{mL})$. Interestingly, further rumen analysis revealed that the ruminal C2:C4 fatty acids profile (acetic, propionic, butyric, and isobutyric) followed a parallel pattern, whereas FRS supplementation tends to decrease the C2:C4 fatty acid level. Similarly, C5 fatty acids (valeric and Isovaleric acid) and caproic acid (C6) showed the same trend, whereas $\mathrm{FRS}_{15}$ was the lowest concentrations for valeric, Isovaleric, and caproic acids (1.38, 1.02, and $0.219 \mathrm{~mol} / \mathrm{L}$, respectively) (Table 4). 
Table 4. Rumen fermentation characteristics in lactating buffaloes fed the four experimental diets.

\begin{tabular}{|c|c|c|c|c|c|c|c|c|}
\hline \multirow{2}{*}{ Item } & \multicolumn{4}{|c|}{ Diets ${ }^{1}$} & \multirow{2}{*}{ SEM } & \multicolumn{3}{|c|}{$p$-Value ${ }^{2}$} \\
\hline & $\mathrm{FRS}_{0}$ & FRS $_{15}$ & $\mathrm{FRS}_{25}$ & FRS $_{35}$ & & Diet & $\mathbf{L}$ & $\mathbf{Q}$ \\
\hline $\mathrm{pH}$ & 6.92 & 7.00 & 6.98 & 7.05 & 0.0476 & 0.4122 & 0.1561 & 0.9019 \\
\hline Ammonia nitrogen, $\mathrm{mg} / \mathrm{dL}$ & 6.51 & 6.83 & 5.39 & 5.43 & 0.3633 & 0.3157 & 0.1656 & 0.8443 \\
\hline $\mathrm{MCP}, \mathrm{mg} / \mathrm{mL}$ & $2.52^{b}$ & $3.25^{b}$ & $5.85^{\mathrm{a}}$ & $2.05^{b}$ & 0.4408 & $<0.0001$ & 0.4804 & $<0.0001$ \\
\hline Acetic acid, mmol/L & 28.07 & 20.28 & 24.51 & 24.83 & 2.0031 & 0.1432 & 0.5719 & 0.0717 \\
\hline Propionic acid, $\mathrm{mmol} / \mathrm{L}$ & $23.30^{\mathrm{a}}$ & $14.98^{b}$ & $19.72^{a b}$ & $20.35^{a b}$ & 1.6139 & 0.0398 & 0.6014 & 0.0202 \\
\hline Acetic/Propionic & $1.20^{\mathrm{b}}$ & $1.36^{\mathrm{a}}$ & $1.24^{\mathrm{ab}}$ & $1.22^{b}$ & 0.0287 & 0.0215 & 0.6402 & 0.0122 \\
\hline Butyric acid, mmol/L & $21.65^{\mathrm{a}}$ & $14.36^{\mathrm{b}}$ & $17.24^{\mathrm{ab}}$ & $20.01^{a b}$ & 1.5380 & 0.0428 & 0.7821 & 0.0087 \\
\hline Isobutyric acid, $\mathrm{mmol} / \mathrm{L}$ & 1.78 & 1.41 & 1.66 & 1.72 & 0.1120 & 0.2010 & 0.8890 & 0.0850 \\
\hline Valeric acid, mmol/L & $2.47^{\mathrm{a}}$ & $1.38^{\mathrm{b}}$ & $2.10^{a b}$ & $2.27^{\mathrm{a}}$ & 0.1873 & 0.0149 & 0.8974 & 0.0071 \\
\hline Isovaleric acid, $\mathrm{mmol} / \mathrm{L}$ & 1.34 & 1.02 & 1.27 & 1.16 & 0.0826 & 0.1062 & 0.4770 & 0.2326 \\
\hline Caproic acid, mmol/L & 0.342 & 0.219 & 0.324 & 0.347 & 0.0461 & 0.2630 & 0.5872 & 0.1462 \\
\hline
\end{tabular}

${ }^{\mathrm{a}, \mathrm{b}}$ LSM within the same row with different superscripts differ $(p<0.05) .{ }^{1}$ Experimental diets were composed of forage and concentrates (83:17), with targeted levels of forage rape silage (FRS):corn silage (CS) $=0: 100,15: 85,25: 75$, and 35:65 on an FM basis. ${ }^{2} \mathrm{~L}=$ linear effect; $\mathrm{Q}=$ quadratic effect.

\subsection{Milk Yield and Composition}

The daily milk yield in buffaloes was not influenced by forage rage silage supplementation. However, FRS numerically improved some milk components, such as the concentrations of milk protein, milk fat, total solids (TS), non-fat milk solid (SNF), casein, saturated fatty acids (SFA), and monounsaturated fatty acids (MUFA) $(p<0.05)$, when compared with that in the $\mathrm{FRS}_{0}$ group (Table 5). The milk lactose concentration remained unchanged with the supplementation of FRS $(p=0.0734)$. The milk urea concentration showed a significant response $(p=0.0385)$ to FRS levels, and the $\mathrm{FRS}_{35}$ diet resulted in the highest concentration compared to FRS $0, \mathrm{FRS}_{15}$, and $\mathrm{FRS}_{25}$. The SNF concentrations in $\mathrm{FRS}_{25}$ and $\mathrm{FRS}_{35}$ treatments were higher than $\mathrm{FRS}_{0}$ and $\mathrm{FRS}_{15}$.

Table 5. Milk yield and milk composition in lactating buffaloes fed the four experimental diets.

\begin{tabular}{|c|c|c|c|c|c|c|c|c|}
\hline \multirow{2}{*}{ Parameter } & \multicolumn{4}{|c|}{ Diets $^{1}$} & \multirow{2}{*}{ SEM } & \multicolumn{3}{|c|}{$p$-Value ${ }^{2}$} \\
\hline & FRS $_{0}$ & $\mathrm{FRS}_{15}$ & $\mathrm{FRS}_{25}$ & $\mathrm{FRS}_{35}$ & & Diet & $\mathbf{L}$ & $\mathbf{Q}$ \\
\hline Milk, kg/day & 5.11 & 5.30 & 5.26 & 4.80 & 0.9565 & 0.9534 & 0.7518 & 0.6380 \\
\hline Protein, \% & 4.08 & 4.12 & 4.26 & 4.66 & 0.1712 & 0.1121 & 0.0190 & 0.5727 \\
\hline Fat, $\%$ & 7.34 & 7.55 & 7.98 & 8.55 & 0.5318 & 0.1335 & 0.0221 & 0.6403 \\
\hline Lactose, \% & 5.59 & 5.26 & 5.59 & 5.46 & 0.1389 & 0.0734 & 0.8861 & 0.3219 \\
\hline Urea, mg/dL & $20.34^{a b}$ & $17.50^{b}$ & $19.01^{a b}$ & $21.26^{\mathrm{a}}$ & 1.3034 & 0.0385 & 0.3080 & 0.0095 \\
\hline TS, $\%$ & 17.47 & 17.23 & 18.36 & 19.04 & 0.6984 & 0.0532 & 0.0126 & 0.3582 \\
\hline SNF, \% & $10.08^{a b}$ & $9.74^{\mathrm{b}}$ & $10.34^{\mathrm{a}}$ & $10.39^{a}$ & 0.2171 & 0.0202 & 0.0321 & 0.2139 \\
\hline Casein, \% & 2.68 & 2.70 & 2.89 & 3.00 & 0.1457 & 0.1080 & 0.0187 & 0.6555 \\
\hline SFA, \% & 4.81 & 4.93 & 5.14 & 5.55 & 0.3744 & 0.2354 & 0.0494 & 0.5921 \\
\hline MUFA, \% & 2.29 & 2.35 & 2.56 & 2.69 & 0.1821 & 0.1210 & 0.0199 & 0.7481 \\
\hline
\end{tabular}

a,b LSM within the same row with different superscripts differ $(p<0.05) .{ }^{1}$ Experimental diets were composed of forage and concentrates (83:17), with targeted levels of forage rape silage (FRS):corn silage (CS) $=0: 100,15: 85,25: 75$, and 35:65 on an FM basis. ${ }^{2} \mathrm{~L}=$ linear effect; $\mathrm{Q}=$ quadratic effect.

\subsection{Blood Parameters}

As showin in Table 6, the $\mathrm{FRS}_{15}$ and $\mathrm{FRS}_{25}$ diets significantly increased blood glucose, total protein, total globulins, and blood urea nitrogen concentration compared with the other treatments. The FRS 15 and $\mathrm{FRS}_{25}$ diets significantly $(p<0.0001)$ decreased the blood HDL concentration compared to $\mathrm{FRS}_{0}$ and $\mathrm{FRS}_{35}$. The $\mathrm{FRS}_{15}$ diet resulted in the highest total blood protein content $(130.21 \mathrm{~g} / \mathrm{L})$ among all the treatments. No differences were observed for total cholesterol (TC), LDL, and liver enzymes (ALT, AST, LD, and GGT) between the different diets. 
Table 6. Blood parameters in lactating buffaloes fed the four experimental diets.

\begin{tabular}{|c|c|c|c|c|c|c|c|c|}
\hline \multirow{2}{*}{ Parameter } & \multicolumn{4}{|c|}{ Diets $^{1}$} & \multirow{2}{*}{ SEM } & \multicolumn{3}{|c|}{$p$-Value ${ }^{2}$} \\
\hline & FRS $_{0}$ & FRS $_{15}$ & FRS $_{25}$ & $\mathrm{FRS}_{35}$ & & Diet & L & $\mathbf{Q}$ \\
\hline $\mathrm{Glu}, \mathrm{mmol} / \mathrm{L}$ & $4.52^{b}$ & $6.29^{a}$ & $5.91^{\mathrm{a}}$ & $4.69^{b}$ & 0.4877 & 0.0030 & 0.9362 & 0.0003 \\
\hline $\mathrm{TC}, \mathrm{mmol} / \mathrm{L}$ & 7.40 & 7.96 & 7.81 & 7.17 & 0.3264 & 0.0893 & 0.4299 & 0.0170 \\
\hline $\mathrm{TP}, \mathrm{g} / \mathrm{L}$ & $99.92^{b}$ & $130.21^{\mathrm{a}}$ & $104.35^{b}$ & $97.85^{b}$ & 8.6030 & 0.0041 & 0.2525 & 0.0067 \\
\hline $\mathrm{TG}, \mathrm{mmol} / \mathrm{L}$ & $2.57^{\mathrm{b}}$ & $3.44^{\mathrm{a}}$ & $3.32^{\mathrm{a}}$ & $2.57^{b}$ & 0.1497 & $<0.0001$ & 0.8065 & $<0.0001$ \\
\hline $\mathrm{LDL}, \mathrm{mmol} / \mathrm{L}$ & 3.25 & 3.53 & 3.39 & 3.30 & 0.1756 & 0.4168 & 0.9823 & 0.1509 \\
\hline $\mathrm{HDL}, \mathrm{mmol} / \mathrm{L}$ & $1.43^{\mathrm{a}}$ & $1.02^{b}$ & $1.04^{b}$ & $1.41^{\mathrm{a}}$ & 0.0900 & $<0.0001$ & 0.8873 & $<0.0001$ \\
\hline $\mathrm{BUN}, \mathrm{mmol} / \mathrm{L}$ & $6.65^{b}$ & $7.17^{a b}$ & $7.47^{\mathrm{a}}$ & $6.20^{b}$ & 0.2885 & 0.0014 & 0.2670 & 0.0003 \\
\hline ALT, U/L & 39.37 & 39.57 & 34.21 & 38.04 & 3.2667 & 0.3499 & 0.3758 & 0.4412 \\
\hline AST, U/L & 28.79 & 26.92 & 22.40 & 32.71 & 6.6176 & 0.4894 & 0.7331 & 0.2078 \\
\hline $\mathrm{LD}, \mathrm{U} / \mathrm{L}$ & 721.32 & 616.73 & 692.31 & 659.92 & 54.448 & 0.2838 & 0.5352 & 0.3596 \\
\hline GGT, U/L & 45.12 & 45.41 & 50.10 & 44.38 & 4.0831 & 0.5024 & 0.8496 & 0.3106 \\
\hline
\end{tabular}

${ }^{\mathrm{a}, \mathrm{b}}$ LSM within the same row with different superscripts differ $(p<0.05) .{ }^{1}$ Experimental diets were composed of forage and concentrates (83:17), with targeted levels of forage rape silage (FRS):corn silage (CS) $=0: 100,15: 85,25: 75$, and 35:65 on an FM basis. ${ }^{2} \mathrm{~L}=$ linear effect; $\mathrm{Q}=$ quadratic effect.

\section{Discussion}

As mentioned in previous studies, brassicas forages contain anti-nutritional sulphur compounds, such as S-methyl cysteine sulphoxide and glucosinolate, which are highly associated with a strong and distinct flavor that affects feed palatability [6] and milk composition, and causes manufacturing complications [11,29]. The current results showed that FRS supplementation improved the DMI, contrary to the previous studies that reported feeding kale (Brassica oleracea) decreased the DMI when offered solely to dairy cows [30]. Although Keim et al. [31] reported that fresh forage rape did not alter dairy cows' DMI, this difference is due to fresh form compared to ensilaged forage rape. Additionally, the negative impact of glucosinolate was diluted through the ensilaging process through the microbial inoculants, which enhanced glucosinolate microbial hydrolysis and supported ruminal flora degradation activity $[32,33]$.

In the $\mathrm{FRS}_{0}$ group, the apparent total-tract fiber-fractions digestibility was the lowest compared to the FRS diets, which resulted from the diet's low NDF and ADF content accompanied by a high level of water-soluble carbohydrates. This latter factor depressed the fiber fractions' digestibility, improved the ruminal VFA content and decreased the ruminal $\mathrm{pH}$, as stated in previous studies [34,35], which can be observed from the short-chain fatty acids (SCFA) content and $\mathrm{pH}$ level in the present study. On the other hand, consistent with Lambert et al. [36], the FRS 15 and $\mathrm{FRS}_{25}$ diets recorded a higher digestibility for DM, $\mathrm{OM}$, and NDF due to the dietary balance between readily fermentable carbohydrates and low content hemicellulose and cellulose in brassica forage [9]. However, the $\mathrm{FRS}_{35}$ level seems to be a suppressor for DM, OM, and fiber digestibility consistent with its high NDF content that dampens nutrient digestibility [37], besides the high concentration of S-methyl cysteine sulphoxide, which is mainly found in brassica-fed stock [6]. Additionally, the ATTD of $\mathrm{N}$ increased due to the increasing dietary $\mathrm{CP}$ content between the groups; these findings are supported by Schulz et al. [38].

Ruminal $\mathrm{pH}$ values were in the normal range for healthy buffalo [39] and in agreement with Kaur and Garcia findings, which stated that FR inclusion could not alter $\mathrm{pH}$ levels [40]. As it is known, the role of NDF can promote chewing activity and increase the salivarybuffer flow to the rumen [41,42]; this explanation is also integrated by previous studies that highlighted the role of high-NDF digestion in raising the ruminal $\mathrm{pH}$ above 6.3 [43]. Although we observed the ruminal ammonia $\mathrm{N}$ decline in $\mathrm{FRS}_{25}$ and $\mathrm{FRS}_{35}$, it was not significantly affected by FRS inclusion, which agrees with previous studies [40,44]. The $\mathrm{FRS}_{25}$ diet resulted in the lowest ammonia N, because of the microbial recapture for volatile $\mathrm{N}$ in the rumen and utilizing it in microbial growth. Consequently, the $\mathrm{FRS}_{25}$ diet led to the highest level of microbial protein synthesis due to the dietary balance between $\mathrm{C}$ and $\mathrm{N}$ that increased the microbial protein content. On the other hand, the ruminal 
VFA decreased by FRS inclusion compared to the $\mathrm{FRS}_{0}$ diet, attributable to $\mathrm{FRS}_{0}$ dietary characteristics concerning the highest content in water-soluble carbohydrate and the lowest in fiber fractions (NDF and ADF), which also explains the highest ruminal VFA values for the $\mathrm{FRS}_{0}$ diet. Correspondingly, the ruminal VFA content followed a rising pattern from $\mathrm{FRS}_{15}$ to $\mathrm{FRS}_{35}$, and that molar proportion of VFAs fractions increased the acetic:propionic ratio; also, the SCFA (C2:C4) Medium-chain fatty acids (MCFAs)was increasingly similar to [45], which responded to an increasing DMI in the FRS groups.

In agreement with Seguel et al.'s [46] results, the milk yield was not affected by FRS inclusion; this resulted from the higher acetic:propionic ratio that directs the energy utilization toward butterfat at the expense of milk yield [47]. This statement is likely to agree with the numerical improvement pattern in fat content among the FRS groups. Similarly, milk urea showed a positive correlation with FRS inclusion, partly explained by the increased dietary $\mathrm{CP}$ content that promotes surplus amino acid catabolism, which alters the urea pool $[2,3,48]$. The significant rise in milk solids not fat (SNF) was associated with higher milk protein synthesis; this finding is similar to Rugoho [49] report's about feeding dairy cows with kale (Brassica oleracea) and its positive effect on milk solids content. Both the milk SFA and MUFA improvement in the FRS groups responded to the improvement in the $\mathrm{C} 2: \mathrm{C} 3$ and $\mathrm{C} 4: \mathrm{C} 5$ ruminal fatty acids profile.

In the present study, blood glucose correlated positively with the ruminal propionate content, which stimulates insulin and alters the glucose level [50], which disagreed with previous reports [51] due to age and species difference. Furthermore, in concordance with a previous study [52], blood globulins in $\mathrm{FRS}_{15}$ and $\mathrm{FRS}_{25}$ groups were significantly higher, which can be indicative of the glucosinolate intake that increases the liver size and hepatic activity [53], leading to more liver globulins production that increases total globulin and total protein. However, the contradicted values for LDL and TC in the FRS 15 and FRS 25 groups were similar to previous studies that reported the concentration ratio's role in the expression extent of the glucosinolate effect [54]. Additionally, the dietary CP intake is the furthermost reported reason for increasing blood urea levels as described by $[2,51,55]$.

\section{Conclusions}

This study confirmed the potential of FRS inclusion in early-mid lactating buffalo diets without a detrimental effect on milk production performance and the ruminal fermentation pattern, which may expand the usage of this forage type in buffalo diets by recommending $\mathrm{FRS}_{15}$ and $\mathrm{FRS}_{25}$ levels. Thus, the current results will strengthen our knowledge about the efficient utilization of forage rape and other brassicas forage types. However, this study cannot answer the nutritional value and feasibility of the ensilaging process, which can minimize the identified limitation for forage rape. Thus, further comparative investigations are needed, especially for examining the ensilaging effect on physiological and ruminal kinetics.

Author Contributions: Conceptualization, L.Y. and G.H.; methodology, D.Z., L.Y. and G.H.; formal analysis, D.Z. and M.A.; investigation, D.Z., X.Z., J.Y., S.Y., Z.A., B.W., G.Z. and K.N.; writingoriginal draft preparation, D.Z. and M.A.; writing-review and editing, D.Z., M.A., L.Y., G.H., Y.G. and J.L.; supervision, L.Y. and G.H.; project administration, L.Y. and G.H.; funding acquisition, L.Y. and G.H. All authors have read and agreed to the published version of the manuscript.

Funding: This research was funded by Hubei provincial technology innovation project (2017ABA057), China Agriculture Research System of MOF and MARA, Key Research and Development Program in Hubei Province (2020BBB061).

Institutional Review Board Statement: The animal study was reviewed and approved by The Ethical Committee of the Hubei Research Center of Experimental Animals (Approval ID: SCXK (Hubei) 20080005).

Informed Consent Statement: Not applicable. 
Data Availability Statement: The datasets used and/or analyzed during the current study are available from the corresponding author.

Acknowledgments: Special thanks to Wu Wenqing and Wang Fan of Huazhong Agricultural University for their technical support and performing the tests. We greatly acknowledge the donation of Compound silage agent by Shandong Zhuohua Biological Company, Jinan, China.

Conflicts of Interest: The authors declare that the research was conducted in the absence of any commercial or financial relationships that could be construed as a potential conflict of interest.

\section{References}

1. Hausman, G.J.; Basu, U.; Du, M.; Fernyhough-Culver, M.; Dodson, M.V. Intermuscular and intramuscular adipose tissues: Bad vs. good adipose tissues. Adipocyte 2014, 3, 242-255. [CrossRef]

2. Serrapica, F.; Masucci, F.; Romano, R.; Napolitano, F.; Sabia, E.; Aiello, A.; di Francia, A. Effects of chickpea in substitution of Soybean meal on milk production, blood profile and reproductive response of primiparous buffaloes in early lactation. Animals 2020, 10, 515. [CrossRef] [PubMed]

3. Serrapica, F.; Masucci, F.; Romano, R.; Santini, A.; Manzo, N.; Seidavi, A.; Omri, B.; Salem, A.Z.M.; di Francia, A. Peas may be a candidate crop for integrating silvoarable systems and dairy buffalo farming in southern Italy. Agrofor. Syst. 2020, 94, 1345-1352. [CrossRef]

4. Sacchi, R.; Marrazzo, A.; Masucci, F.; Di Francia, A.; Serrapica, F.; Genovese, A. Effects of inclusion of fresh forage in the diet for lactating buffaloes on volatile organic compounds of milk and mozzarella cheese. Molecules 2020, 25, 1332. [CrossRef]

5. Uzun, P.; Masucci, F.; Serrapica, F.; Napolitano, F.; Braghieri, A.; Romano, R.; Manzo, N.; Esposito, G.; di Francia, A. The inclusion of fresh forage in the lactating buffalo diet affects fatty acid and sensory profile of mozzarella cheese. J. Dairy Sci. 2018, 101, 6752-6761. [CrossRef] [PubMed]

6. Rawnsley, R.P.; Chapman, D.F.; Jacobs, J.L.; Garcia, S.C.; Callow, M.N.; Edwards, G.R.; Pembleton, K.P. Complementary forages-Integration at a whole-farm level. Anim. Prod. Sci. 2013, 53, 976-987. [CrossRef]

7. De Ruiter, J.M.; Fletcher, A.; Maley, S.; Sim, R.; George, M. Aiming for 45 t/ha per Annum: Yield of Supplementary Feed Crops Grown in Sequences Designed for Maximum Productivity; NZ Grassland Association: Dunedin, New Zealand, 2009; pp. $107-116$.

8. Jeromela, A.M.; Mikić, A.M.; Vujić, S.; Ćupina, B.; Krstić, D.; Dimitrijević, A.; Vasiljević, S.; Mihailović, V.; Cvejić, S.; Miladinović, D. Potential of legume-Brassica intercrops for forage production and green Manure: Encouragements from a temperate southeast european environment. Front. Plant Sci. 2017, 8, 312. [CrossRef]

9. Barry, T.N. The feeding value of forage brassica plants for grazing ruminant livestock. Anim. Feed Sci. Technol. 2013, 181, 15-25. [CrossRef]

10. Westwood, C.T.T. Nutritional Evaluation of Five Species of Forage Brassica; NZ Grassland Association: Dunedin, New Zealand, 2012; pp. 31-37.

11. Moate, P.J.; Dalley, D.E.; Grainger, C.; Goudy, A.; Clarke, T.; Williams, P.; Limsowtin, G. Effect of feeding turnips on the concentration of thiocyanate in milk and consequences for cheese making. Aust. J. Dairy Technol. 1996, 51, 1-5.

12. Williams, S.R.O.; Moate, P.J.; Deighton, M.H.; Hannah, M.C.; Wales, W.J.; Jacobs, J.L. Milk production and composition, and methane emissions from dairy cows fed lucerne hay with forage brassica or chicory. Anim. Prod. Sci. 2016, 56, 304-311. [CrossRef]

13. Nichol, W.; Westwood, C.; Dumbleton, A.; Amyes, J. Brassica wintering for dairy cows: Overcoming the challenges. In Proceedings of the South Island Dairy Event (SIDE), Canterbury, New Zealand, 7 June 2003; pp. 154-172.

14. Jonker, J.S.; Kohn, R.A.; Erdman, R.A. Using milk urea nitrogen to predict nitrogen excretion and utilization efficiency in lactating dairy cows. J. Dairy Sci. 1998, 81, 2681-2692. [CrossRef]

15. AOAC International. Official Methods of Analysis of Aoac International; AOAC International: Arlington, VA, USA, 1995.

16. McCarthy, J.F.; Aherne, F.X.; Okai, D.B. Use of $\mathrm{HCl}$ insoluble ash as an index material for determining apparent digestibility with pigs. Can. J. Anim. Sci. 1974, 54, 107-109. [CrossRef]

17. Van Keulen, J.; Young, B.A. Evaluation of acid-insoluble ash as a natural marker in ruminant digestibility studies. J. Anim. Sci. 1977, 44, 282-287. [CrossRef]

18. Van Soest, P.J.; Wine, R.H. Use of detergents in the analysis of fibrous feeds. IV. Determination of plant cell-wall constituents. J. Assoc. Off. Anal. Chem. 1967, 50, 50-55. [CrossRef]

19. Van Soest, P.J.; Robertson, J.B.; Lewis, B.A. Methods for dietary fiber, neutral detergent fiber, and nonstarch polysaccharides in relation to animal nutrition. J. Dairy Sci. 1991, 74, 3583-3597. [CrossRef]

20. McDonald, P.; Henderson, A.R. Determination of water-soluble carbohydrates in grass. J. Sci. Food Agric. 1964, 15, 395-398. [CrossRef]

21. Shen, J.S.; Chai, Z.; Song, L.J.; Liu, J.X.; Wu, Y.M. Insertion depth of oral stomach tubes may affect the fermentation parameters of ruminal fluid collected in dairy cows. J. Dairy Sci. 2012, 95, 5978-5984. [CrossRef]

22. Niu, J.; Li, Y.; Gao, Y.; Li, J. Effects of dietary active dry yeast on rumen fermentation characteristics and nutrient apparent digestibility of lactating dairy cows. Chin. J. Anim. Nutr. 2019, 31, 3338-3345. [CrossRef]

23. Weatherburn, M.W. Phenol-hypochlorite reaction for determination of ammonia. Anal. Chem. 1967, 39, 971-974. [CrossRef] 
24. Hu, W.; Liu, J.; Wu, Y.; Guo, Y.; Ye, J. Effects of tea saponins on in vitro ruminal fermentation and growth performance in growing Boer goat. Arch. Anim. Nutr. 2006, 60, 89-97. [CrossRef]

25. Laporte, M.F.; Paquin, P. Near-infrared analysis of fat, protein, and casein in cow's milk. J. Agric. Food Chem. 1999, 47, $2600-2605$. [CrossRef]

26. Nasrollahi, S.M.; Ghorbani, G.R.; Zali, A.; Kahyani, A. Feeding behaviors, metabolism, and performance of primiparous and multiparous dairy cows fed high-concentrate diets. Livest. Sci. 2017, 198, 115-119. [CrossRef]

27. Wang, Z.; Wu, Y.; Shi, L.; Cui, L.; Li, X.; He, C.; Yang, L. Evaluation and mining the applicable methods of roughage digestibility determination for buffalo (Bubalus bubalis). Trop. Anim. Health Prod. 2020, 52, 2639-2646. [CrossRef] [PubMed]

28. Sales, J.; Janssens, G.P.J. Acid-insoluble ash as a marker in digestibility studies: A review. J. Anim. Feed Sci. 2003, 12, 383-401. [CrossRef]

29. Wiedenhoeft, M.H.; Barton, B.A. Taste quality of milk from dairy cows fed forage Brassica cv. Tyfon. J. Sustain. Agric. 1995, 5, 139-146. [CrossRef]

30. Keogh, B.; French, P.; Murphy, J.J.; Mee, J.F.; McGrath, T.; Storey, T.; Grant, J.; Mulligan, F.J. A note on the effect of dietary proportions of kale (Brassica oleracea) and grass silage on rumen $\mathrm{pH}$ and volatile fatty acid concentrations in dry dairy cows. Livest. Sci. 2009, 126, 302-305. [CrossRef]

31. Keim, J.P.; Daza, J.; Beltrán, I.; Balocchi, O.A.; Pulido, R.G.; Sepúlveda-Varas, P.; Pacheco, D.; Berthiaume, R. Milk production responses, rumen fermentation, and blood metabolites of dairy cows fed increasing concentrations of forage rape (Brassica napus ssp. Biennis). J. Dairy Sci. 2020, 103, 9054-9066. [CrossRef]

32. Alexander, J.; Auðunsson, G.A.; Benford, D.; Cockburn, A.; Cravedi, J.; Dogliotti, E.; Di Domenico, A.; Férnandez-cruz, M.L.; Fürst, P.; Galli, C.L.; et al. Glucosinolates as undesirable substances in animal feed-Scientific Opinion of the Panel on Contaminants in the Food Chain. EFSA J. 2008, 6, 1-76. [CrossRef]

33. Brabban, A.D.; Edwards, C. Isolation of glucosinolate degrading microorganisms and their potential for reducing the glucosinolate content of rapemeal. FEMS Microbiol. Lett. 1994, 119, 83-88. [CrossRef]

34. Lee, M.R.F.; Merry, R.J.; Davies, D.R.; Moorby, J.M.; Humphreys, M.O.; Theodorou, M.K.; MacRae, J.C.; Scollan, N.D. Effect of increasing availability of water-soluble carbohydrates on in vitro rumen fermentation. Anim. Feed Sci. Technol. 2003, 104, 59-70. [CrossRef]

35. Mould, F.L.; Ørskov, E.R. Manipulation of rumen fluid $\mathrm{pH}$ and its influence on cellulolysis in sacco, dry matter degradation and the rumen microflora of sheep offered either hay or concentrate. Anim. Feed Sci. Technol. 1983, 10, 1-14. [CrossRef]

36. Lambert, M.G.; Abrams, S.M.; Harpster, H.W.; Jung, G.A. Effect of hay substitution on intake and digestibility of forage rape (Brassica napus) fed to lambs. J. Anim. Sci. 1987, 65, 1639-1646. [CrossRef]

37. Armstrong, R.H.; Beattie, M.M.; Robertson, E. Intake and digestibility of components of forage rape (Brassica napus) by sheep. Grass Forage Sci. 1993, 48, 410-415. [CrossRef]

38. Schulz, F.; Westreicher-Kristen, E.; Knappstein, K.; Molkentin, J.; Susenbeth, A. Replacing maize silage plus soybean meal with red clover silage plus wheat in diets for lactating dairy cows. J. Dairy Sci. 2018, 101, 1216-1226. [CrossRef] [PubMed]

39. Akbar, M.A.; Kumari, R. Ruminal pH as Regulator of Rumen Metabolism in Buffaloes. Buffalo Bull. 2006, $25,432$.

40. Kaur, R.; Garcia, S.C. Rumen degradation and fermentation characteristics of forage rape. In Proceedings of the 4th Australasian Dairy Science Symposium, Christchurch, New Zealand, 31 August-2 September 2010; pp. 321-325.

41. Allen, M.S.; Voelker, J.A.; Oba, M. Physically effective fiber and regulation of ruminal pH: More than just chewing. In Production Diseases in Farm Animals; Wageningen Academic Publishers: Wageningen, The Netherlands, 2006; pp. $270-278$.

42. Gazzola, P.; Boyle, L.; French, P.; Hanlon, A.J.; Mulligan, F.J. The effect of three feeding systems on metabolic status and foraging behaviour of out-wintered cows. In Proceedings of the Irish Grassland and Animal Production, Tullamore, Ireland, 21 June 2008.

43. Mulligan, F.J.; Caffrey, P.J.; Rath, M.; Callan, J.J.; Brophy, P.O.; O'Mara, F.P. An investigation of feeding level effects on digestibility in cattle for diets based on grass silage and high fibre concentrates at two forage: Concentrate ratios. Livest. Prod. Sci. 2002, 77, 311-323. [CrossRef]

44. Sun, X.Z.; Harland, R.; Pacheco, D. Effect of altering ruminal $\mathrm{pH}$ by dietary buffer supplementation on methane emissions from sheep fed forage rape. Animal 2020, 14, 952-962. [CrossRef] [PubMed]

45. Castillo-Umaña, M.; Balocchi, O.; Pulido, R.; Sepúlveda-Varas, P.; Pacheco, D.; Muetzel, S.; Berthiaume, R.; Keim, J.P. Milk production responses and rumen fermentation of dairy cows supplemented with summer brassicas. Animal 2020, 14, 1684-1692. [CrossRef]

46. Seguel, G.; Keim, J.P.; Vargas-Bello-Pérez, E.; Geldsetzer-Mendoza, C.; Ibáñez, R.A.; Alvarado-Gilis, C. Effect of forage brassicas in dairy cow diets on the fatty acid profile and sensory characteristics of Chanco and Ricotta cheeses. J. Dairy Sci. 2020, 103, 228-241. [CrossRef]

47. Bath, D.L. Reducing fat in milk and dairy products by feeding. J. Dairy Sci. 1982, 65, 450-453. [CrossRef]

48. Reiter, J.; Strittmatter, H.; Wiemann, L.O.; Schieder, D.; Sieber, V. Enzymatic cleavage of lignin $\beta-O-4$ aryl ether bonds via net internal hydrogen transfer. Green Chem. 2013, 15, 1373-1381. [CrossRef]

49. Rugoho, I. Intake and Performance of Dairy Cattle on Forages in Winter. Ph.D. Thesis, Lincoln University, Christchurch, New Zealand, 2013.

50. Bedford, A.; Beckett, L.; Hardin, K.; Dias, N.W.; Davis, T.; Mercadante, V.R.G.; Ealy, A.D.; White, R.R. Propionate affects insulin signaling and progesterone profiles in dairy heifers. Sci. Rep. 2018, 8, 1-10. [CrossRef] [PubMed] 
51. Chorfi, Y.; Couture, Y.; Tremblay, G.F.; Berthiaume, R.; Cinq-Mars, D. Growth and Blood Parameters of Weaned Crossbred Beef Calves Fed Forage Kale (Brassica oleracea spp. acephala). Adv. Agric. 2015, 2015, 1-7. [CrossRef]

52. Cox-Ganser, J.M.; Jung, G.A.; Pushkin, R.T.; Reid, R.L. Evaluation of Brassicas in grazing systems for sheep: II. Blood composition and nutrient status. J. Anim. Sci. 1994, 72, 1832-1841. [CrossRef] [PubMed]

53. Vermorel, M.; Davicco, M.-J.; Evrard, J.; Anglaret, Y.; Genest, M.; Leoty, C.; Meyer, M.; Souchet, R. Valorization of rapeseed meal. 3. Effects of glucosinolate content on food intake, weight gain, liver weight and plasma thyroid hormone levels in growing rats. Reprod. Nutr. Dév. 1987, 27, 57-66. [CrossRef] [PubMed]

54. Bowland, J.P. Evaluation of low glucosinolate-Low erucic acid rapeseed meals as protein supplements for young growing pigs, including effects on blood serum constituents. Can. J. Anim. Sci. 1975, 55, 409-419. [CrossRef]

55. Wilson, C.; Undi, M.; Tenuta, M.; Wittenberg, K.M.; Flaten, D.; Krause, D.O.; Entz, M.H.; Holley, R.; Ominski, K.H. Pasture productivity, cattle productivity and metabolic status following fertilization of a grassland with liquid hog manure: A three-year study. Can. J. Anim. Sci. 2010, 90, 233-243. [CrossRef] 